\title{
Patients' Satisfaction with Healthcare Delivery in the Gambia: A Case Study of Edward Francis Small Teaching Hospital
}

\author{
Yusupha Sanyang \\ Department of Nursing and Reproductive Health, University of the Gambia, The Gambia \\ E-mail: ysanyang@utg.edu.gm
}

Ismaila Bojang (Corresponding Author)

Department of Economics and Management Sciences, University of the Gambia, The Gambia

E-mail: bojissbo@gmail.com

Dr. Francis Sarr

Department of Nursing and Reproductive Health, University of the Gambia, The Gambia

E-mail: sarrfrancis2@gmail.com

Received: Jan. 7, 2019 Accepted: Feb. 27, 2019 Published: April 19, 2019

doi:10.5296/bmh.v7i1.14691 URL: http://dx.doi.org/10.5296/bmh.v7i1.14691

\begin{abstract}
The aim of the study was to assess the satisfaction of patients about the services provided at the Edward Francis Small Teaching Hospital (EFSTH) in the Gambia. A cross-sectional study design was used to evaluate how the patients view the healthcare services provided at the EFSTH. The main research question is "what is the satisfaction level of patients about the services provided at the EFSTH". The SERVQUAL tool was used to collect data from a sample of 250 patients receiving care at the EFSTH. This sample was chosen using the systematic random sampling method. The variable of the study that were measured are satisfaction, expectations and perceptions of patients about the services they received. Data was collected from the outpatient and inpatient department of the hospital. The quantitative data was analyzed using SPSS statistical tool for descriptive statistics, mainly involving the
\end{abstract}




\section{Macrothink}

percentages, and the results are presented in tables and charts. The study found out that most of the patients have higher expectations and a low level of perception of the services provided at the EFSTH. There was a low level of patient satisfaction with the hospital services as only $36.8 \%$ of the patients strongly agree that they are satisfied with the hospital services provided. The findings also showed that most of the respondents regarded doctors' services as the most important services provided at the hospital. There is only one service feature (housekeeping) with a positive quality gap score of 2.19667 indicating high quality of services and high patient satisfaction.

There is a low level of patient's satisfaction about the services provided at the EFSTH which is tied to a low level of service quality.

Keywords: satisfaction, expectation, perception, service quality, hospital service 


\section{MlMacrothink}

\section{Introduction}

The healthcare system is experiencing unprecedented demands for services, which ultimately impacts on hospital resources and the quality of the care provided by both medical and nursing professionals (Dey, Hariharan, \& Brookes, 2006). As patient satisfaction has become pivotal in quality assessment of healthcare systems in developed countries, interest in patient satisfaction assessment is growing in developing countries. Whilst there are studies of patient satisfaction with healthcare services in some African countries, such as Nigeria, where the patient satisfaction aspect of hospital care has been highlighted (Muhondwa, Leshabari, Mwangu, Mbembati, \& Ezekiel, 2008) These studies found that patients were most satisfied with staff-patient relationships. However, patients were dissatisfied with the amount of time they could spend with their doctors. Such studies have never been done in the Gambia.

However, there are no validated tools to reliably assess patient satisfaction with healthcare services in the Gambian context which consequently makes patient satisfaction with healthcare services largely unknown. This situation can really affect the quality of healthcare services as assessment of patients' satisfaction can help improve the delivery of healthcare services and optimize resource utilization (Malewski, Ream, \& Gaither, 2015). From the patient perspective, research suggests that satisfied patients are more likely to continue a relationship with one health care practitioner, participate in their own health care, adhere to their treatment regimens and have better health outcomes (Aharony \& Strasser, 1993; Horvat \& Kos, 2010, 2011). With the information highlighted above, it becomes imperative to investigate patient satisfaction with healthcare services offered in the Gambian hospitals as this will aid in developing intervention and training programs designed toenhance healthcare services that meet and by extension exceed patients' expectations.

\subsection{Research Objectives}

To determine whether patients are satisfied with the services provided at the EFSTH

To describe the expectations of patients toward services offered at the EFSTH

To describe the perception of patients towards services offered at the EFSTH

To make policy recommendation for the improvement of patient care at the EFSTH

\subsection{Research Questions}

The researcher aims to find answers to the following questions below:

1) Are patients satisfied with the level of services provided at the Edward Francis Small Teaching Hospital?

2) Does the current level of service delivery at EFSTH meet customer expectation?

3) What are patient's perceptions of the services provided at the EFSTH?

\subsection{Research Justification}

As a result of the scanty and skeleton body of knowledge regarding patient satisfaction in the 
Gambia, it was extremely imperative to conduct an empirical investigation in order to provide insight into the nature and level of satisfaction regarding service delivery. In addition to that, the research findings from this study will serve as a spring board for subsequent future research as well as lay the foundation for the development of a national validated tool for the assessment of satisfaction among healthcare consumers in the Gambia. Moreover, the findings of the study will enable stakeholders in the healthcare delivery system to improve the quality delivery and management process.

\section{Theoretical Review}

\subsection{Patient Satisfaction: A Determinant of Quality of Healthcare Service}

Patient satisfaction is considered "a personal evaluation or appraisal of a service or product received (Donabedian, 1997).Assessment of patients' satisfaction can help improve the delivery of healthcare services and optimize resource utilization (Curtiss, Fry, \& Avey, 2004).As such, patient satisfaction is an integral component of the quality assurance of healthcare servicesand has gained much attention for the purposes of performance assessment, reimbursement, and quality management of health service delivery (Donabedian, 1997). Some studies suggest that satisfied patients are more likely to continue using healthcare services compared to unsatisfied ones (Dearmin, Brenner, \& Migliori, 1995; Pascoe, 1983), while other studies have linked satisfaction with medication compliance (Bartlett et al., 1984; Pascoe, 1983)and continuity with care providers(Bartlett et al., 1984; Crosby, Evans, \& Cowles, 1990). It is no wonder, then, that patient satisfaction is animportant humanistic outcome to achieve along with clinical and economic outcomes.

Patient satisfaction has become a driver of quality as affordable care organizations expand and health care market competition grows (Kassam, Collins, \& Berkowitz, 2012; MacKeigan \& Larson, 1989). Organizations such as the U.S. Agency for Healthcare Research and Quality (AHRQ) and Centre for Medicare and Medicaid Services (CMS) recognize the importance of patient satisfaction as a quality metric through the Consumer Assessment of Healthcare Providers and Systems (CAHPS) survey program.

Patient satisfaction is vital for continuous monitoring and quality improvement of health care delivery systems (Ford, Bach, \& Fottler, 1997). From the patient perspective, research suggests that satisfied patients are more likely to continue a relationship with one health care practitioner, participate in their own health care, adhere to their treatment regimens and have better health outcomes (Aharony \& Strasser, 1993; Horvat \& Kos, 2010, 2011). A patient satisfaction system should address each patient's medical care and service needs at the "point-of-care" before the patient leaves the medical facility. It should be patient centered, by actively involving each patient in his /her own healthcare evaluation planning and continuous quality improvement. Patient needs are aligned with the required healthcare resources which simultaneously produces better and efficient results (Sommers, Dropik, Heilman, \& Vaughan, 2007). Patient satisfaction is a highly desirable outcome of clinical care in the hospital and may even be an element of health status itself. A patient's expression of satisfaction or dissatisfaction is a judgment on the quality of hospital care in all its aspects whatever its strengths and limitations. Patient satisfaction is an indication that should be indispensable to 
the assessment of the quality of care in hospitals (Torscon, 2005). Assessment of quality usually focuses on technical concerns as well as the process through which care is delivered.

This assessment becomes more authentic and legitimate if based on the application of professional standards integrating the patients' views, experiences and perceptions. However, an effective system can only function properly, if it operates on a regular assessment of people's perceptions and monitors itself based on their feedback (Sajid \& Baig, 2007). Parasuraman, Zeithaml, \& Berry, (1985) explained satisfaction in relation to service quality.They argued that service quality is defined as the gap between predicted or expected service (customer expectations) and perceived service (customer perceptions). If customers' expectation is greater than performance, then perceived quality is regarded less than satisfactory and a service quality gap arises. This in effect does not necessarily mean that the service is of low quality but rather customer expectations have not been met and therefore customer dissatisfaction occurs and these present opportunities for improving service to meet customer expectations. During 2004 and 2005, a focus group interview was conducted by the Agency of Health Care Research and Quality and Centre for Medicare and Medicaid Services (CMS) to find out how patients perceive the quality of health care. In this study, it was observed that patients, usually, preferred four qualities of health care services viz. doctor communication skill, responsiveness of hospital staff, comfort and cleanliness of the hospital environment and communication of nursing staff (Safavi, 2006).

\subsection{Determinants of Patient Satisfaction}

Several studies report that Patient's satisfaction is influenced by a number of factors and according to (Peprah \& Atarah, 2014) the following factors play a critical role in the satisfaction of patients; the attitudes of nurses toward patients, the capacity to deliver prompt service without wasting time, ability to disseminate information to patients and the availability of up-to-date equipment. Others include the hospital's ability to render 24-hour service, the patience of the doctor to clearly explain what was wrong with patients before giving treatment, providing patients with detailed information about their medication, and attractiveness and cleanliness of the hospital. Patient satisfaction has been associated in the research literature with a variety of nursing factors, but until recent payment incentives, many hospitals have not taken note.

Studies have linked patient satisfaction with nurse-staffing levels, higher proportions of registered nurse (RN) skill-mix, nurses' work environment, and RN-physician collaboration(Bolton et al., 2003). Patients' reports of satisfaction are higher in hospitals where nurses practice in better work environments or with more favourable patient-to-nurse ratios (Kutney-Lee et al., 2009). Expectations are critical as they form the basis for the subjective assessment of care that is the rating of satisfaction. There can be different expectations for different aspects of care and patients with lower expectations tend to be more satisfied (Sitzia \& Wood, 1997).Patient satisfaction is used as a measure of quality of care, research to date suggests that patient satisfaction is related to more than how effectively the physician manages the patient's specific medical problem (Leas, 2006; O'Toole, Castillo, Pollak, MacKenzie, \& Bosse, 2008; Vranceanu \& Ring, 2011). 


\section{Macrothink}

Previous studies, predominantly in the primary care setting, identified time spent with the physician as an important predictor of patient satisfaction (Anderson, Camacho, \& Balkrishnan, 2007; Camacho, Anderson, Safrit, Jones, \& Hoffmann, 2006; Gross, Zyzanski, Borawski, Cebul, \& Stange, 1998; Trout, Magnusson, \& Hedges, 2000). Most of the studies on time spent in the office uses a cross-sectional survey design in which patients are asked - at a time remote from the visit - about their satisfaction and their perceived waiting time and time with the physician (Anderson et al., 2007; Howard, Agarwal, \& Hilts, 2009; Huang, 1994; 2006; Zoller, Lackland, \& Silverstein, 2001)

\subsection{Conceptual Framework}

The service quality model of Parasuraman et al. (1985) is extensively used as a conceptual framework for assessing and measuring service quality delivery in healthcare services. The model suggests that consumers' quality perceptions are influenced by a series of five unique gaps manifesting in the organizations. The gaps originating from the service providers' side impacts service delivery that is perceived by clients as either high or low quality. These gaps are presented below:

(i) The differences between patient expectations and management perceptions of patient's expectations, i.e. not knowing what patients expect;

(ii) The differences between management perceptions of patient expectations and service quality specifications, i.e. improper service-quality standards;

(iii) The differences between service quality specifications and service delivered, i.e. the service performance gap;

(iv) The differences between service delivery and what is communicated about the service to patients;

(v) The differences between patients' expectations and perceptions, which sequentially depends on the size and direction of the four gaps associated with the delivery of service quality on the service provider's side.

Service quality manifest when expectations are met (or exceeded) resulting in satisfaction, and a service gap occurs if expectations are not met also producing dissatisfaction (Parasuraman et al., 1985).

The gap score for each statement is calculated by deducting the expectation score from perception score. The manifestation of a positive gap score suggest that expectations have been met or exceeded and a negative score also means that expectations are not being met. Gap scores can be analyzed for individual statements and can be aggregated to give an overall gap score for each dimension.

Pakdil \& Harwood (2005) found SERVQUAL a useful model to measure the differences between patients' preferences and their actual experiences. According to Rohini \& Mahadevappa (2006), SERVQUAL instrument is 'parsimonious' and has standardized analysis procedure to aid interpretations and results in hospitals in Bangalore. According to 


\section{Macrothink}

Business and Management Horizons

ISSN 2326-0297

2019, Vol. 7, No. 1

Chunlaka (2010), SERVQUAL helps understand what the customers' value is all about and how well an organization meets the needs and expectation of consumers of hospitals. Qin \& Prybutok, (2009) mentioned all the five dimensions of the service quality in SERVQUAL instrument are significant and reliable in a health care setting

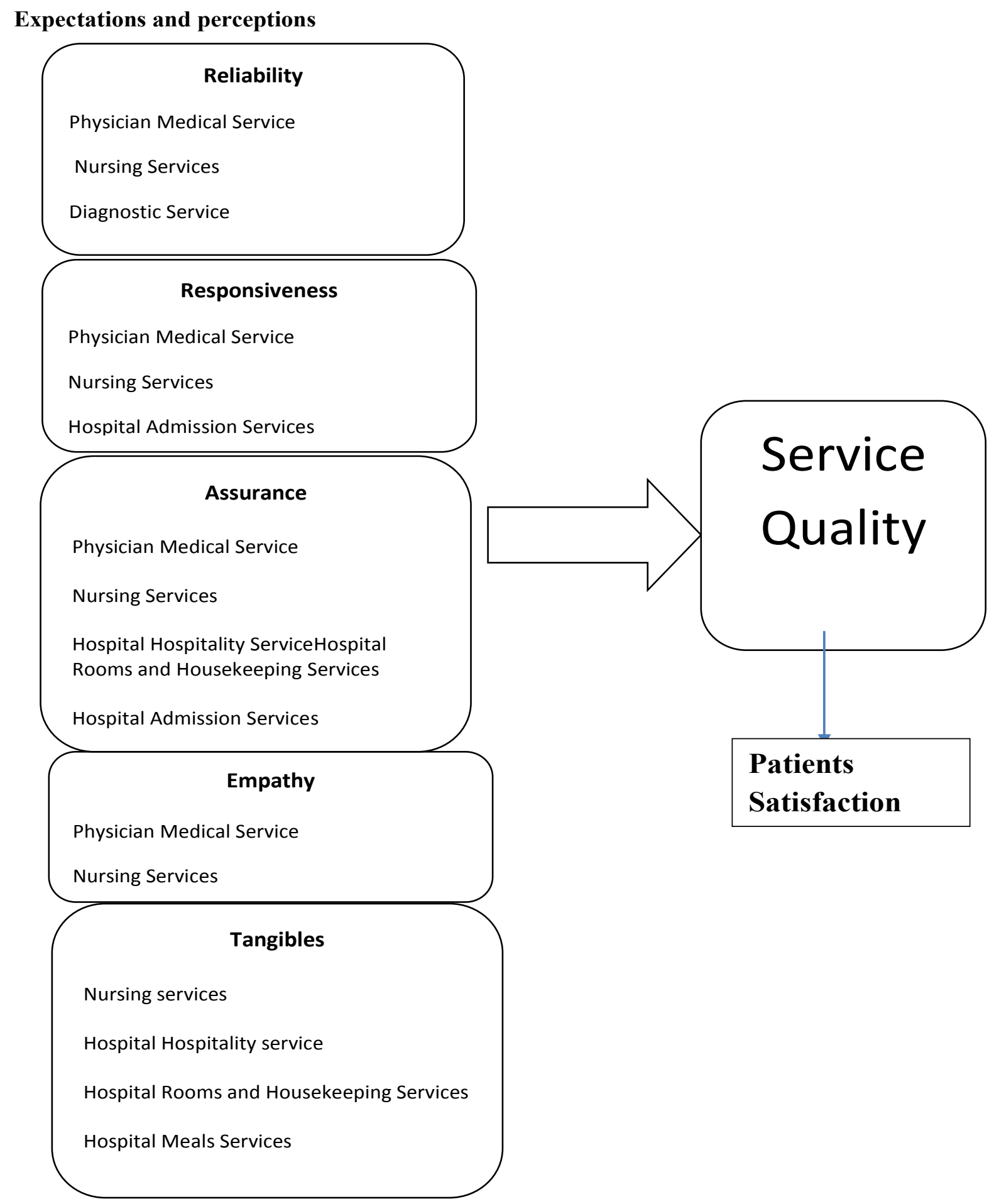

Figure 1. "SERVQUAL" Model 


\section{Methodology}

The study was a cross sectional study designed with a survey questionnaire and the data was collected at the Edward Francis Small Teaching Hospital. It is the main referral and the only teaching hospital in the Gambia, and therefore served as the pinnacle of the healthcare in the Gambia. The sample size comprised of 250 participants who were patients/clients attending treatment at the EFSTH. The systematic random sampling method was used to select the participants of the study. This was done by systematically arranging patients' hospital file numbers to ensure that everyone has an equal chance of being selected. The participants that were included in the study were patients/clients that were fully conscious and are not in any form of distress. The participants were asked to sign consent forms before they were included in the study. Participants that did not meet the criteria were excluded from the study. These include unconscious patients, patients in distress and escorts and relatives of patient. The SERVQUAL instrument developed by Parasuraman et al. (1985) was adopted for the study. This tool is a valid and reliable tool that has been used in assessing satisfaction level in different organizations and it has also been proven that it can be used in healthcare settings.

Data was collected at the EFSTH. The questionnaire was self-administered to the respondents who were able read and understand the English Language. It was also interpreted in the local languages to the respondents who did not understand the English language. The data was collected by the researcher from both inpatients and outpatient departments of the hospital. The respondents were assured of confidentiality and their response will no way influence the treatment they are receiving. They were advised to read the instruction carefully and respond to it accordingly. Eight service dimensions of the hospital was assessed to find out the patients' satisfaction with the service at the hospital. The service dimensions include the Hospital Premises and Employees, Nursing Service, Doctors' Service, Diagnostic Service, Admission Services, Meal Services, Discharge Service, and Housekeeping Services. The seven-point Likert scale was used to determine the patient expectation and perception of each of the service dimension of the hospital.

The quantitative data was analyzed using the statistical tool "SPSS" version 20.0 for descriptive as well as analytical analysis to determine the patient level of satisfaction. The Cronbach's alpha was calculated for reliability.

The research proposal was sent to The Research and Scientific committee of the School of Medicine and Allied Health Sciences for approval. It was afterwards submitted to the Hospital Ethics Committee and the Joint Gambia Government/ Medical Research Council Ethics Committee for clearance to conduct the study. A participant information sheet and a consent form were also attached to each questionnaire explaining in summary the purpose of this study. Additional information was also provided when needed to reinforce the information on the consent form.

\subsection{Instrument Reliability and Validity}

The SERVQUAL instrument developed by Parasuraman et al. (1985) was adopted for this study. Its reliability stood the test of time as it has been used in assessing satisfaction levels in 
different organizations which of course includes health care settings. Furthermore, for the purpose of this study, the instrument was subjected to a preliminary pilot test in order to uncover the loopholes that might exist as well as explain the instrument to the respondents chosen for the pilot.

\section{Research Findings}

The data was analyzed using SPSS assessing respondents' satisfaction about hospital services. Meanwhile, simple descriptive statistics in the form of percentages as well as bar charts were used in presenting the results. The Seven-point Likert Scale was used and the following acronyms were used such as Strongly Disagree (SD), Disagree (D), Disagree Somewhat (DS), Undecided (UD), Agree Somewhat (AS), Agree (A) and Strongly Agree (SA).

Table 1. Respondents' expectations of the hospital premises and employees at the EFSTH in percentages

\begin{tabular}{|c|c|c|c|c|c|c|c|}
\hline Variables & SD & $\mathrm{D}$ & DS & UD & $\mathrm{AS}$ & A & SA \\
\hline $\begin{array}{l}\text { E1. Excellent hospitals should have the most } \\
\text { technologically advanced equipment }\end{array}$ & 0 & 0 & 0 & 2 & 4.8 & 10 & 83.2 \\
\hline $\begin{array}{l}\text { E2. The physical facilities (buildings, landscape, physical } \\
\text { layout) at excellent should be visually impressive }\end{array}$ & 0 & 0.4 & 1.6 & 1.6 & 5.2 & 18.4 & 72.8 \\
\hline $\begin{array}{l}\text { E3. Employees at Excellent hospitals should be } \\
\text { extremely neat appearing }\end{array}$ & 0.8 & 0.4 & 0.4 & 2 & 2.4 & 14.4 & 79.6 \\
\hline $\begin{array}{l}\text { E4. Materials associated with the service (pamphlets, } \\
\text { booklets, medical procures) should clearly contain all the } \\
\text { necessary information at excellent hospitals }\end{array}$ & 0 & 0.8 & 0.4 & 2 & 7.6 & 12 & 77.2 \\
\hline AVERAGE EXPECTATION & 0.2 & 0.4 & 0.6 & 1.9 & 5 & 13.7 & 78.2 \\
\hline SUMMARY OF EXPECTATION & & 1.2 & & 1.9 & & 96.9 & \\
\hline
\end{tabular}

\subsection{The Respondents' Expectations of the Hospital Premises and Employees}

The table above summarizes the respondents' expectations about the hospital premises and employees. Most of the respondents $72.8 \%$ strongly agree that the physical facilities should be visually impressive. As for the expectation that the hospital should have the most advanced technological equipment $83.2 \%$ strongly agree, while $79.6 \%$ strongly agree that employees should be neat in appearance. Finally, $77.2 \%$ strongly agree that materials associated with the service (pamphlets, booklets, medical procures) should clearly contain all the necessary information at excellent hospitals.

Table 2. Respondents' perceptions of the hospital premises and employees at the EFSTH in percentages 


\begin{tabular}{|c|c|c|c|c|c|c|c|}
\hline Variables & SD & $\mathrm{D}$ & DS & UD & AS & A & SA \\
\hline P1. EFSTH has the most technologically advanced Equipment & 11.2 & 8.8 & 9.2 & 14.4 & 16.8 & 18.8 & 20.8 \\
\hline $\begin{array}{l}\text { P2. The physical facilities (buildings, landscape, physical } \\
\text { layout) at the EFSTH are visually impressive }\end{array}$ & 2.8 & 7.2 & 10 & 12.8 & 18 & 23.2 & 26 \\
\hline P3. Employees at the EFSTH are extremely neat appearing & 3.2 & 3.2 & 4.8 & 12.4 & 9.6 & 20.4 & 46.4 \\
\hline $\begin{array}{l}\text { P4. Materials associated with the service (pamphlets, } \\
\text { Booklets, medical procures) should clearly contain all the } \\
\text { necessary information at excellent hospitals }\end{array}$ & 5.6 & 2.4 & 4.4 & 7.2 & 14 & 25 & 40.4 \\
\hline $\begin{array}{l}\text { AVERAGE PERCEPTION } \\
\text { SUMARRY OF PERCEPTION }\end{array}$ & $\begin{array}{l}5.7 \\
18.2\end{array}$ & 5.4 & 7.1 & $\begin{array}{l}11.7 \\
11.7\end{array}$ & 14.6 & $\begin{array}{l}21.85 \\
69.85\end{array}$ & 33.4 \\
\hline
\end{tabular}

\subsection{The Respondents' Perceptions of the Hospital Premises and Employees}

The table above summarizes the perception of patients about the hospital premises and employees. $20.8 \%$ of the respondents strongly agree that the EFSTH has the most technologically advanced equipment. As for the perception that the physical facilities of the hospital are visually impressive, 26\% strongly agreed, while $46.4 \%$ strongly agreed that the hospital employees are always neat in appearance. Finally, 40.4\% strongly agreed that the materials associated with the service (pamphlets, Booklets, medical procures) clearly contain all the necessary information at excellent hospitals

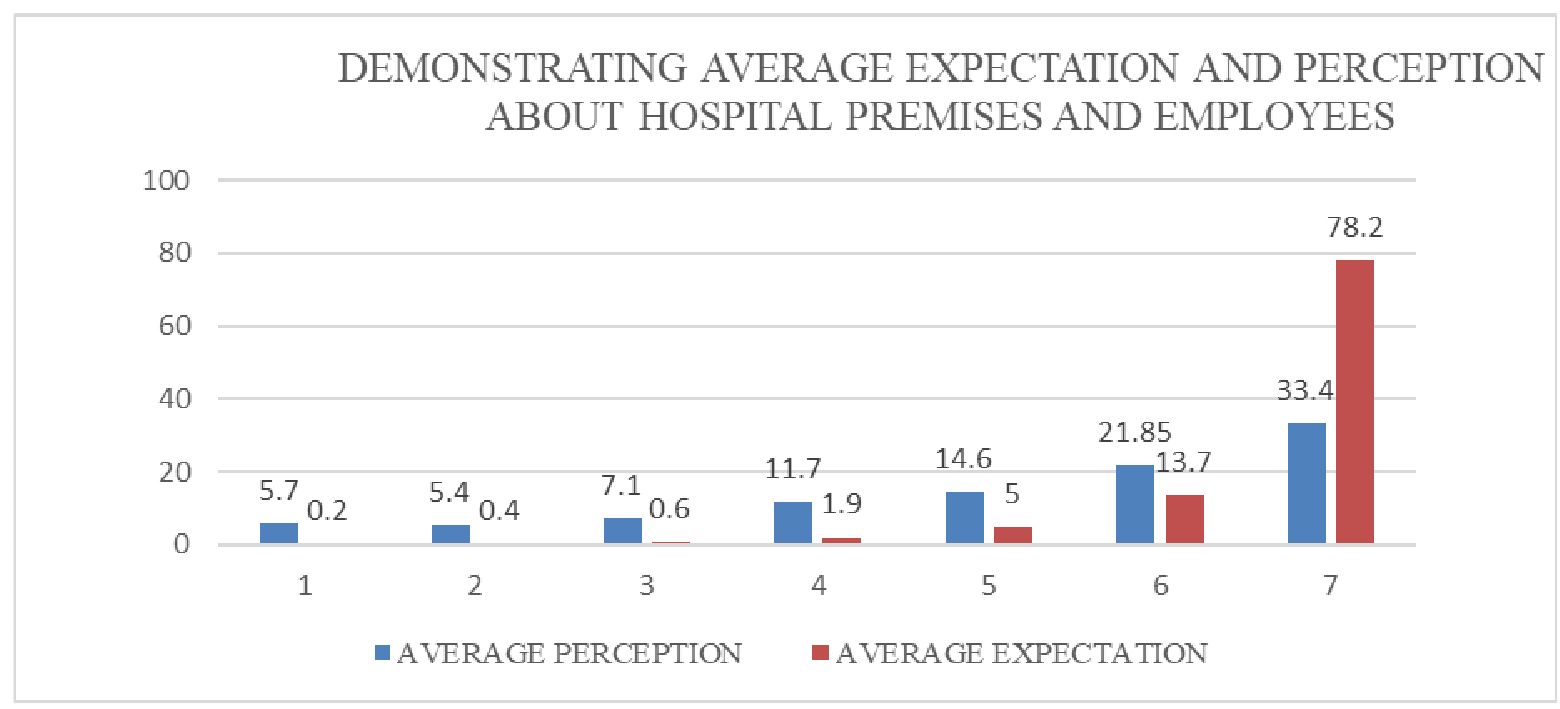

Figure 2. Average expectations and perception of hospital premises and employees

Table 3. Respondents' expectations of the doctors' services at the EFSTH in percentages 


\begin{tabular}{|c|c|c|c|c|c|c|c|}
\hline Variables & SD & D & DS & UD & AS & A & SA \\
\hline E5. Doctors in EFSTH should always be on time & 1.2 & 1.6 & 0.0 & 0.4 & 5.2 & 10.0 & 81.6 \\
\hline $\begin{array}{l}\text { E6. Patients of ESFTH should feel extremely safe in their } \\
\text { transactions }\end{array}$ & 0.8 & 0.4 & 1.2 & 2.0 & 5.2 & 17.2 & 73.2 \\
\hline $\begin{array}{l}\text { E7. Doctors in EFSTH should have very high level of } \\
\text { knowledge required to answer patient's questions } \\
\text { satisfactorily }\end{array}$ & 0.4 & 2.0 & 0.8 & 1.6 & 1.6 & 8.4 & 85.2 \\
\hline $\begin{array}{l}\text { E8. EFSTH should have an experienced doctor who } \\
\text { areaware of the patient's case available at all time of my } \\
\text { hospital stay. }\end{array}$ & 0.4 & 1.6 & 1.2 & 1.2 & 4.0 & 12.0 & 79.6 \\
\hline $\begin{array}{l}\text { E9. Doctors in EFSTH should hear very carefully what the } \\
\text { patient has to say }\end{array}$ & 2.0 & 0.8 & 0.8 & 0.4 & 4.8 & 8.4 & 82.8 \\
\hline $\begin{array}{l}\text { E10.Doctors in EFSTH should be extremely careful in } \\
\text { explaining what the patient is expected to do in words she } \\
\text { understands }\end{array}$ & 1.2 & 1.2 & 1.2 & 1.2 & 2.4 & 12.4 & 80.4 \\
\hline $\begin{array}{l}\text { E11.Doctors in EFSTH should spend enough time with the } \\
\text { patient }\end{array}$ & 0.8 & 0.4 & 0.8 & 2.0 & 6.0 & 18.0 & 72.0 \\
\hline $\begin{array}{l}\text { E12.Doctors in EFSTH should examine the patient very } \\
\text { carefully before deciding what is wrong with me }\end{array}$ & 0.4 & 2.0 & 0.4 & 0.4 & 4.0 & 9.6 & 83.2 \\
\hline $\begin{array}{l}\text { E13.Doctors in EFSTH should always treat the patient with } \\
\text { respect }\end{array}$ & 1.2 & 0.4 & 1.2 & 0.0 & 4.4 & 8.8 & 84.0 \\
\hline $\begin{array}{l}\text { E14. Where the patient's medical care is concerned, doctors } \\
\text { in EFSTH should discuss all decisions with the he }\end{array}$ & 1.2 & 1.2 & 1.2 & 0.8 & 7.6 & 12.0 & 76.0 \\
\hline E15.Doctors in EFSTH should have excellent reputations & 2.0 & 0.4 & 0.0 & 0.0 & 4.0 & 12.4 & 81.2 \\
\hline $\begin{array}{l}\text { E16.Doctors in EFSTH should be university professors or } \\
\text { major consultants }\end{array}$ & 2.4 & 0.8 & 0.4 & 2.4 & 5.6 & 16.0 & 72.4 \\
\hline $\begin{array}{l}\text { E17.Doctors in EFSTH should be accredited with the } \\
\text { highest medical degrees }\end{array}$ & 0.8 & 1.2 & 0.8 & 2.4 & 7.2 & 12.0 & 75.6 \\
\hline AVEREGAE EXPECTATIONS & 1.14 & 1.08 & 0.77 & 1.14 & 4.77 & 12.09 & 79.02 \\
\hline SUMMARY OF EXPECTATIONS & 2.98 & & & 1.14 & & & 95.88 \\
\hline
\end{tabular}

\subsection{The Respondents' Expectations of the Doctor's Services}

The table above describes the patients' expectations of the doctors' services at the EFSTH. Majority of the patients $81.6 \%$ strongly agree that the doctors are always on time, $73.2 \%$ also strongly believed that patient should feel extremely safe with their transactions with doctors. $85.4 \%$ also strongly agree that there should be an experienced doctor who is aware of patient's case and is available at all times.

Table 4. Respondents' perceptions of the doctors at the EFSTH in percentages 


\begin{tabular}{|c|c|c|c|c|c|c|c|}
\hline Variables & SD & $\mathrm{D}$ & DS & UD & AS & A & SA \\
\hline P5. Doctors in EFSTH are always on time & 14.8 & 4.0 & 8.4 & 9.2 & 18.0 & 18.4 & 27.2 \\
\hline $\begin{array}{l}\text { P6. Patients of excellent hospitals feel extremely safe in their } \\
\text { transactions }\end{array}$ & 14.8 & 4.0 & 8.4 & 9.2 & 18.0 & 18.4 & 27.2 \\
\hline $\begin{array}{l}\text { P7. Doctors in EFSTH have very high level of knowledge } \\
\text { required to answer my questions satisfactorily }\end{array}$ & 14.8 & 4.0 & 8.4 & 9.2 & 18.0 & 18.4 & 27.2 \\
\hline $\begin{array}{l}\text { P8. EFSTHhospitals have an experienced doctor who is } \\
\text { aware my case available at all times of my hospital stay }\end{array}$ & 14.8 & 4.0 & 8.4 & 9.2 & 18.0 & 18.4 & 27.2 \\
\hline P9. Doctors in EFSTH hear very carefully what I have to say & 14.8 & 4.0 & 8.4 & 9.2 & 18.0 & 18.4 & 27.2 \\
\hline $\begin{array}{l}\text { P10. Doctors in EFSTH are extremely careful in explaining } \\
\text { what I am expected to do in words I understands }\end{array}$ & 14.8 & 4.0 & 8.4 & 9.2 & 18.0 & 18.4 & 27.2 \\
\hline P11. Doctors in EFSTH spend enough time with me & 14.8 & 4.0 & 8.4 & 9.2 & 18.0 & 18.4 & 27.2 \\
\hline $\begin{array}{l}\text { P12.Doctors in EFSTH examine me very carefully before } \\
\text { deciding what is wrong with me }\end{array}$ & 14.8 & 4.0 & 8.4 & 9.2 & 18.0 & 18.4 & 27.2 \\
\hline P13. Doctors in EFSTH always treat the me with respect & 14.8 & 4.0 & 8.4 & 9.2 & 18.0 & 18.4 & 27.2 \\
\hline $\begin{array}{l}\text { P14. Where my medical care is concerned, doctors in EFSTH } \\
\text { discuss all decisions with me }\end{array}$ & 14.8 & 4.0 & 8.4 & 9.2 & 18.0 & 18.4 & 27.2 \\
\hline P15.Doctors in EFSTH have excellent reputations & 14.8 & 4.0 & 8.4 & 9.2 & 18.0 & 18.4 & 27.2 \\
\hline $\begin{array}{l}\text { P16.Doctors in EFSTH are university professors or major } \\
\text { consultants }\end{array}$ & 14.8 & 4.0 & 8.4 & 9.2 & 18.0 & 18.4 & 27.2 \\
\hline $\begin{array}{l}\text { P17.Doctors in EFSTH are accredited with the highest } \\
\text { medical degrees }\end{array}$ & 14.8 & 4.0 & 8.4 & 9.2 & 18.0 & 18.4 & 27.2 \\
\hline AVERAGE PERCEPTION & 14.8 & 4.0 & 8.4 & 9.2 & 18.0 & 18.4 & 27.2 \\
\hline SUMMARY OF PERCEPTION & 27.2 & & & 9.2 & & 63.6 & \\
\hline
\end{tabular}

\subsection{The Respondents' Perceptions of the Doctors' Services}

The table above describes the perceptions of patients about the doctors' services. There is a general reduction in the percentage of patient's perceptions of the doctors. the respondents who strongly agree that doctors are always on time is $27.2 \%$ strongly agreed, patients feel extremely safe in their transactions was $36.0 \%$ strongly agreed, doctors have high level of knowledge required to answer my questions $40.8 \%$ strongly agreed, EFSTH have experience doctors who are aware of my case and available at times $34.0 \%$ strongly agreed, doctors at the EFSTH hear very carefully what I have to say, doctors are extremely careful in explaining what I am expected to do in words I understands $40.0 \%$ strongly agreed, spend enough time with me $23.6 \%$ strongly agreed, doctors at the EFSTH examine me very carefully before deciding what is wrong with me $46.0 \%$ strongly agreed, treat me with respect $49.6 \%$, discuss all decisions with me $36.0 \%$, have excellent reputations, $41.6 \%, 27.6 \%$ strongly agree. 


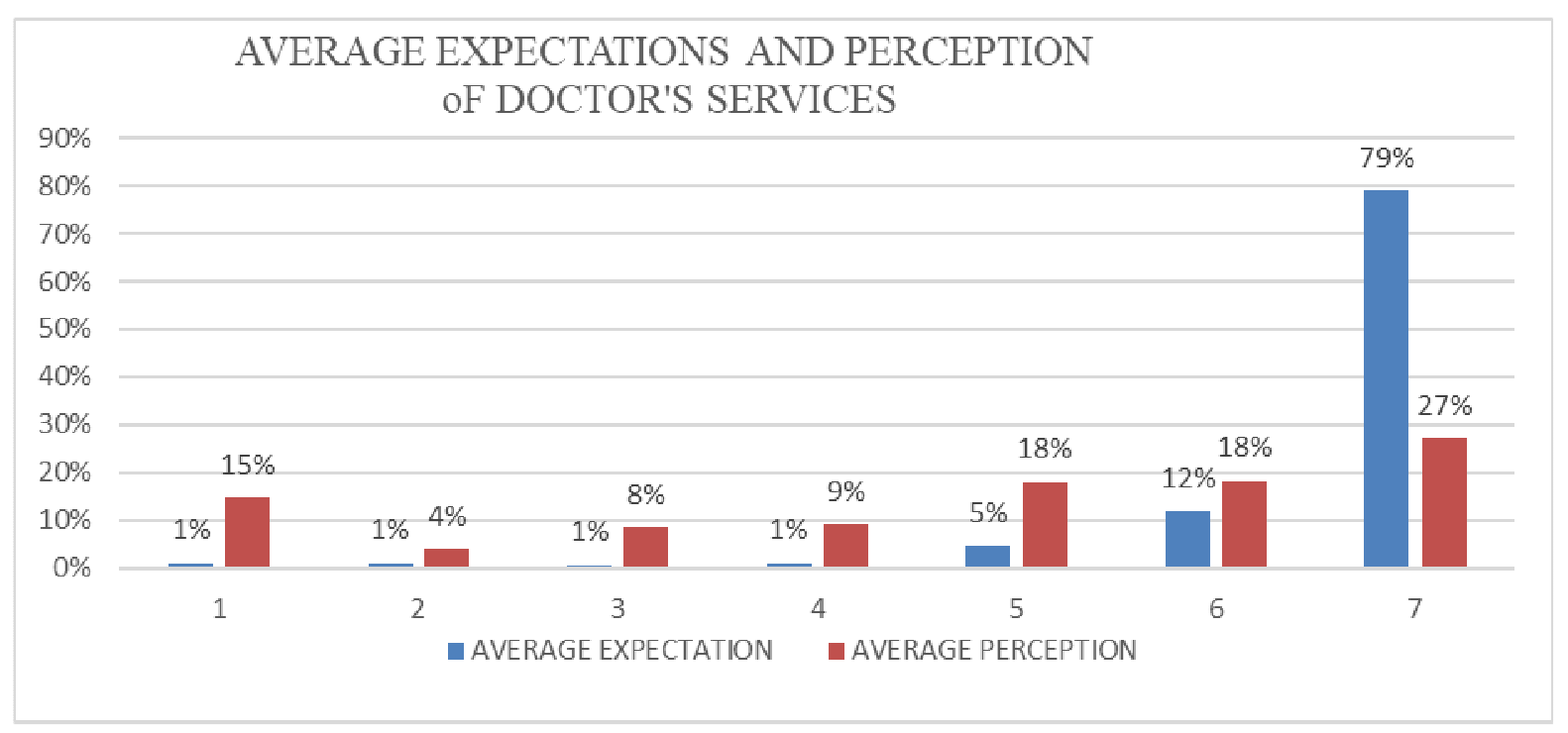

Figure 3. Average expectations and perceptions of doctors' services

Table 5. Respondents' expectations of the diagnostic services at EFSTH in percentages

\begin{tabular}{llllllll}
\hline Variables & SD & D & DS & UD & AS & A & SA \\
\hline $\begin{array}{l}\text { E18.Doctors in EFSTH never order any unnecessary } \\
\text { diagnostic medical procedures }\end{array}$ & 3.6 & 2.8 & 2.8 & 6.4 & 6.8 & 14 & 63.6 \\
$\begin{array}{l}\text { E19.Laboratory and X-ray technicians in EFSTH should } \\
\text { have high technical skills required to perform the service }\end{array}$ & 0.8 & 1.2 & 0 & 0.4 & 3.2 & 10.8 & 83.6 \\
$\begin{array}{l}\text { E20.Lab tests and X-rays EFSTH should always be done } \\
\text { right the first time }\end{array}$ & 0.4 & 1.6 & 0.8 & 1.2 & 4.4 & 13.2 & 78.4 \\
$\begin{array}{l}\text { E21.Lab tests and X-rays EFSTH should always be } \\
\text { provided at the time they are promised }\end{array}$ & 0.8 & 2 & 0 & 0.8 & 3.6 & 14.8 & 78 \\
AVEARGE EXPECTATION & & & & & & & \\
SUMARY OF EXPECTATION & 1.4 & 1.9 & 0.9 & 2.2 & 4.5 & 13.2 & 75.9 \\
& 4.2 & & & 2.2 & & & 93.6 \\
\hline
\end{tabular}

\subsection{The Respondents' Expectations of the Diagnostic Services}

The table summarizes the expectations of respondents about the diagnostics services at the EFSTH. Majority of the respondents $63.6 \%$ strongly agreed that doctors never order any unnecessary test, on laboratory technicians should have high technical skills $83.6 \%$ strongly agree, lab tests and X-rays should be done right the first time $78.4 \%$ strongly agree and finally as for lab tests and X-rays at the EFSTH should always be provided at the time they are promised $78.0 \%$ strongly agree 
Table 6. Respondents' perceptions of the diagnostic services at EFSTH in percentages

\begin{tabular}{llllllll}
\hline Variables & SD & D & DS & UD & AS & A & SA \\
\hline $\begin{array}{l}\text { P18.Doctors in EFSTH never order any unnecessary } \\
\text { diagnostic procedure }\end{array}$ & 13.6 & 5.2 & 5.6 & 13.2 & 14 & 15.2 & 33.2 \\
$\begin{array}{l}\text { P19.Laboratory and X-ray technicians in EFSTH have } \\
\text { high technical skills required to perform the services }\end{array}$ & 4.4 & 6.8 & 4.8 & 15.2 & 12.8 & 23.2 & 32.8 \\
$\begin{array}{l}\text { P20.Lab tests and X-rays in EFSTH are always done } \\
\text { right the first time }\end{array}$ & 9.6 & 9.6 & 6 & 10.4 & 17.2 & 16.4 & 30.8 \\
$\begin{array}{l}\text { P21.Lab tests and X-rays in EFSTH are always } \\
\text { provided at the time they are promised }\end{array}$ & 7.2 & 9.2 & 8 & 16 & 16 & 16.8 & 26.8 \\
$\begin{array}{l}\text { AVERAGE PERCEPTION } \\
\text { SUMMARY OF PERCEPTION }\end{array}$ & 8.7 & 7.7 & 6.1 & 13.7 & 15 & 17.9 & 30.9 \\
\hline
\end{tabular}

\subsection{The Respondents' Perceptions of the Diagnostic Services}

The table 5 summarizes the respondents' perceptions of the diagnostics services at the EFSTH. There is a marked difference between the perceptions of respondents' and their expectations. Doctors never order unnecessary diagnostic procedure $33.2 \%$ strongly agree and for the statement that laboratory and X-ray technicians have high skills required to perform services $32.8 \%$ strongly agree, lab test and X-rays are always done right at the first time $30.8 \%$ agree and lastly lab test and X-rays are always provided at the time they are promised $26.8 \%$

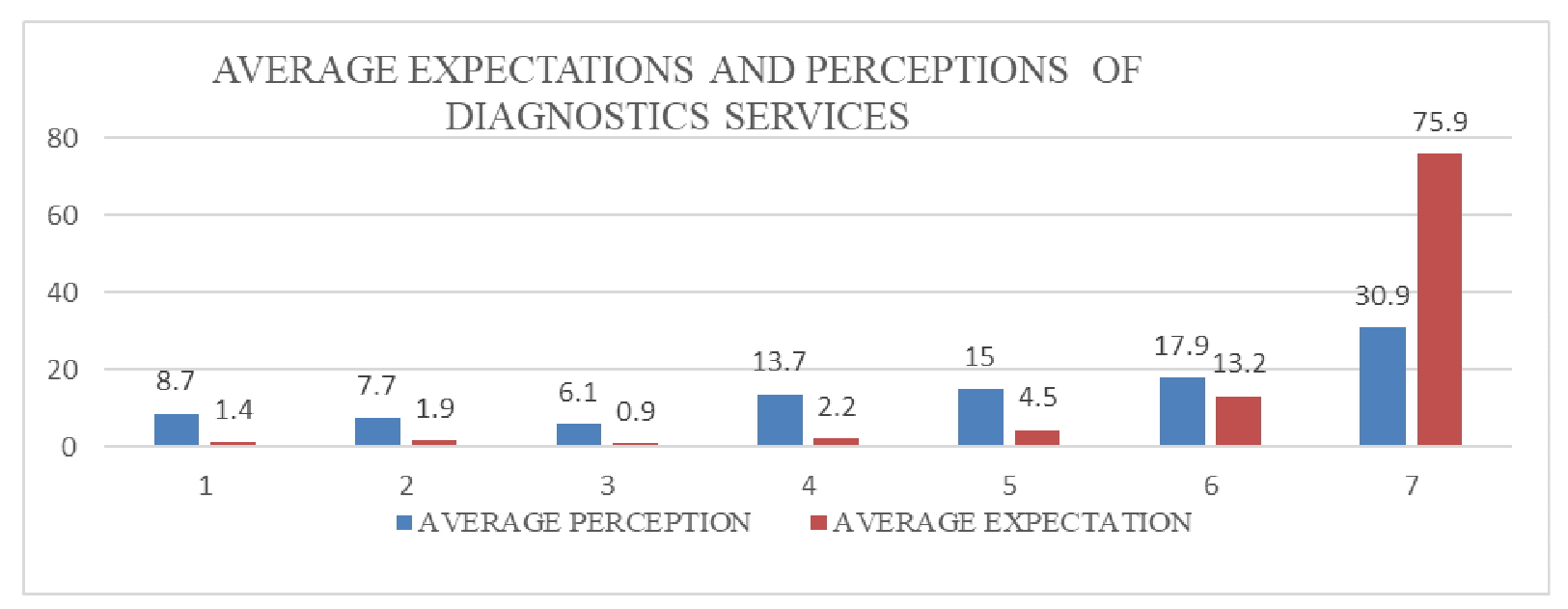

Figure 4. Average expectations and perceptions of diagnostics services

Table 7. Respondents' expectations of the nursing services at the EFSTH in percentages 


\begin{tabular}{|c|c|c|c|c|c|c|c|}
\hline Variables & $\mathrm{SD}$ & $\mathrm{D}$ & $\mathrm{DS}$ & UD & AS & A & SA \\
\hline $\begin{array}{l}\text { E22.Nurses at the EFSTH should have high personal } \\
\text { hygiene (body and mouth odour, nails, cleanliness of } \\
\text { uniforms etc.) }\end{array}$ & 0.8 & 0 & 1.6 & 1.6 & 0.8 & 8.8 & 86.4 \\
\hline $\begin{array}{l}\text { E23.Nurses at the EFSTH should have level of knowledge } \\
\& \text { skill needed to perform the service very well }\end{array}$ & 1.2 & 0.4 & 0 & 1.2 & 4 & 7.6 & 85.6 \\
\hline $\begin{array}{l}\text { E24.Nurses at the EFSTH should perform the service } \\
\text { required (tests, procedures, medication dispensing) at } \\
\text { exactly the right time }\end{array}$ & 0 & 0.4 & 0.4 & 1.6 & 2 & 8.4 & 87.2 \\
\hline $\begin{array}{l}\text { E25.Nurses at the EFSTH should be consistently courteous } \\
\text { to patients }\end{array}$ & 0 & 0.4 & 0.4 & 1.2 & 2 & 9.6 & 86.4 \\
\hline $\begin{array}{l}\text { E26.Nurses at the EFSTH should always communicate in } \\
\text { acceptable language with patients }\end{array}$ & 0.4 & 0.4 & 0.4 & 1.6 & 3.2 & 9.2 & 84.8 \\
\hline $\begin{array}{l}\text { E27.Nurses at the EFSTH should always respond in a } \\
\text { reasonable length of time }\end{array}$ & 0.4 & 0.4 & 0 & 0.8 & 5.2 & 10.8 & 82.4 \\
\hline $\begin{array}{l}\text { E28.Nurses at the EFSTH should give patients personal } \\
\text { attention }\end{array}$ & 0.4 & 0.4 & 1.2 & 0.4 & 4 & 16.4 & 77.2 \\
\hline $\begin{array}{l}\text { E29.Nurses at the EFSTH should understand the specific } \\
\text { needs of their patients }\end{array}$ & 0.8 & 0 & 0 & 1.2 & 4 & 12.8 & 81.2 \\
\hline AVERAGE EXPECTATIONS & 0.5 & 0.3 & 0.5 & 1.2 & 3.15 & 10.45 & 83.9 \\
\hline SUMARRY OF EXPECTATTIONS & 1.3 & & & 1.2 & & & 97.5 \\
\hline
\end{tabular}

\subsection{Respondents' Expectations of the Nursing Services}

The table above summarizes the expectations of respondents about the nursing services at the EFSTH. The respondents generally have a high level of expectations about the nursing services. Majority of them $86.4 \%$ strongly agreed that nurses should have good personal hygiene, nurses should have level of knowledge and skills needed to perform the services very well $85.6 \%$ strongly agreed. Nurses should be consistently courteous $86.4 \%$ and nurses should always communicate in acceptable languages with patients $84.8 \%$ strongly agreed, nurses should always respond in a reasonable length of time $82.4 \%$ strongly agreed, nurses should give patients personal attention $77.2 \%$ strongly agreed and finally nurses at the EFSTH should understand the specific needs of their patients $81.2 \%$ strongly agreed

Table 8. Respondents' Perceptions of the nursing services at the EFSTH in percentages 


\section{Macrothink}

Business and Management Horizons

ISSN 2326-0297

2019, Vol. 7, No. 1

\begin{tabular}{|c|c|c|c|c|c|c|c|}
\hline Variables & SD & D & DS & UD & AS & A & SA \\
\hline $\begin{array}{l}\text { P22. Nurses at the EFSTH have high personal } \\
\text { hygiene (body and mouth odour, nails, cleanliness of } \\
\text { uniforms etc.) }\end{array}$ & 2.8 & 2.4 & 3.2 & 4.8 & 8 & 22.8 & 56 \\
\hline $\begin{array}{l}\text { P23. Nurses at the EFSTH have level of knowledge } \\
\& \text { skill needed to perform the service very well }\end{array}$ & 0 & 4.8 & 3.6 & 6.8 & 13.2 & 30.8 & 40.8 \\
\hline $\begin{array}{l}\text { P24. Nurses at the EFSTH perform the service } \\
\text { required (tests, procedures, medication dispensing) at } \\
\text { exactly the right time }\end{array}$ & 2 & 2.4 & 2.8 & 6 & 16.8 & 24.4 & 45.6 \\
\hline $\begin{array}{l}\text { P25. Nurses at the EFSTH are be consistently } \\
\text { courteous }\end{array}$ & 3.2 & 3.2 & 5.6 & 10 & 12.8 & 24.4 & 40.8 \\
\hline $\begin{array}{l}\text { P26. Nurses at the EFSTH always communicate in } \\
\text { acceptable language with patients }\end{array}$ & 7.2 & 3.6 & 9.6 & 5.2 & 8.4 & 20 & 46 \\
\hline $\begin{array}{l}\text { P27. Nurses at the EFSTH always respond in a } \\
\text { reasonable length of time }\end{array}$ & 6.8 & 4.4 & 7.2 & 7.2 & 18 & 26.4 & 30 \\
\hline P28. Nurses at the EFSTH give me personal attention & 7.2 & 5.2 & 5.2 & 7.2 & 21.6 & 20 & 33.6 \\
\hline $\begin{array}{l}\text { P29. Nurses at the EFSTH understand my specific } \\
\text { needs }\end{array}$ & 5.6 & 3.6 & 3.6 & 12 & 14.4 & 26.4 & 34.4 \\
\hline AVERAGE PERCEPTIONS & 4.35 & 3.7 & 5.1 & 7.4 & 14.15 & 24.4 & 40.9 \\
\hline SUMMARY OF PERCEPTIONS & 13.15 & & & 7.4 & & & 79.45 \\
\hline
\end{tabular}

\subsection{The Respondents'Perceptions of the Nursing Services}

The table above summarizes the perception of respondents about the nursing services at the EFSTH. The perception level of the respondents about the nursing services at the EFSTH is general low. Majority of the respondents $56.0 \%$ strongly agreed that nurses at the EFSTH have high personal hygiene. This is the only statement which has more than $50 \%$ of the respondents strongly agreeing. The rest of the statements have less than $50 \%$ of the respondents strongly agreeing about the nursing services at the EFSTH 


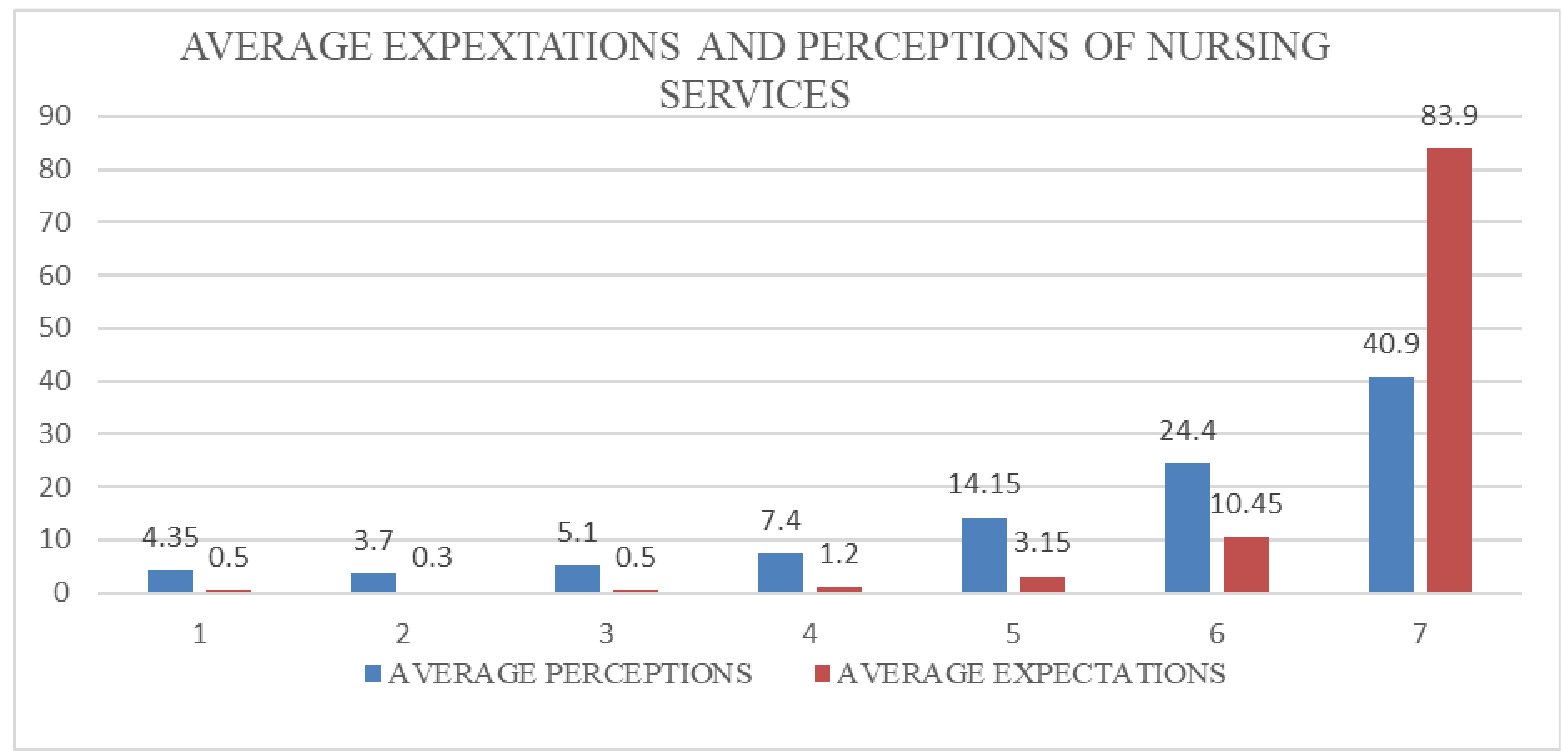

Figure 5. Average expectations and perceptions of nursing services

Table 9. Respondents' expectations of the admission services at the EFSTH in percentages

\begin{tabular}{llllllll}
\hline Variables & SS & D & DS & UD & AS & A & SA \\
\hline E30.In EFSTH, appointments should be made easily & 0.8 & 0.4 & 0 & 2.8 & 7.2 & 9.2 & 79.6 \\
$\begin{array}{l}\text { E31.Admission personnel in EFSTH should provide } \\
\text { clear information (e.g. directions, schedules etc.) to } \\
\text { patients }\end{array}$ & 0.8 & 0.4 & 0 & 0 & 5.6 & 11.2 & 82 \\
& & & & & & & \\
$\begin{array}{l}\text { E32.Admission personnel in EFSTH should be } \\
\text { consistently courteous and helpful to patients }\end{array}$ & 0.8 & 0.8 & 0.4 & 2.4 & 6 & 10 & 79.6 \\
& & & & & & & \\
$\begin{array}{l}\text { AVERAGE EXPECTATIONS } \\
\text { SUMMARY OF EXPECTATIONS }\end{array}$ & 0.8 & 0.5 & 0.1 & 1.7 & 6.2 & 10. & 80.4 \\
\hline
\end{tabular}

\subsection{Respondents' Expectations of the Admission Services}

The table above summarizes the expectations of respondents about the admission services at the EFSTH. The respondents have a high expectation of the admission services at the hospital. Majority of them $79.6 \%$ strongly agree that the appointments should be made easy at the hospital, as for the admission personnel should provide clear information $82.0 \%$ strongly agreed and finally $79.6 \%$ strongly agreed that admission personnel should be consistently courteous and helpful to the patients. 
Table 10: Respondents' perceptions of the admission services at EFSTH in percentages

\begin{tabular}{|c|c|c|c|c|c|c|c|}
\hline Variables & SD & $\mathrm{D}$ & DS & UD & AS & A & SA \\
\hline P30. At the EFSTH, appointments are made easily & 10.4 & 5.6 & 7.6 & 8.8 & 14.8 & 20 & 32.8 \\
\hline $\begin{array}{l}\text { P31. Admission personnel at the EFSTH provide } \\
\text { clear information (e.g. directions, schedules etc.) to } \\
\text { patients }\end{array}$ & 7.6 & 10.8 & 8 & 12.4 & 12 & 20 & 29.2 \\
\hline $\begin{array}{l}\text { E32. Admission personnel at the EFSTH are } \\
\text { consistently courteous and helpful }\end{array}$ & 9.2 & 8 & 8.4 & 14.8 & 12.4 & 24.8 & 22.4 \\
\hline AVERAGE PERCEPTION & 9.1 & 8.1 & 8 & 12 & 13.1 & 21.6 & 28.1 \\
\hline SUMMARY OF PERCEPTIONS & 25.2 & & & 12 & & & 62.8 \\
\hline
\end{tabular}

\subsection{Respondents' Perceptions of the Admission Services}

The table above summarizes the perception of respondents about the services at the EFSTH. The level perception is generally low about the admission services at the hospital. The percentage of respondents that strongly agree that appointments are made easily was $32.8 \%$ strongly agreed, about admission personnel provide clear information to patients $29.2 \%$ strongly agreed and finally $22.4 \%$ strongly agreed that admission personnel are consistently courteous and helpful

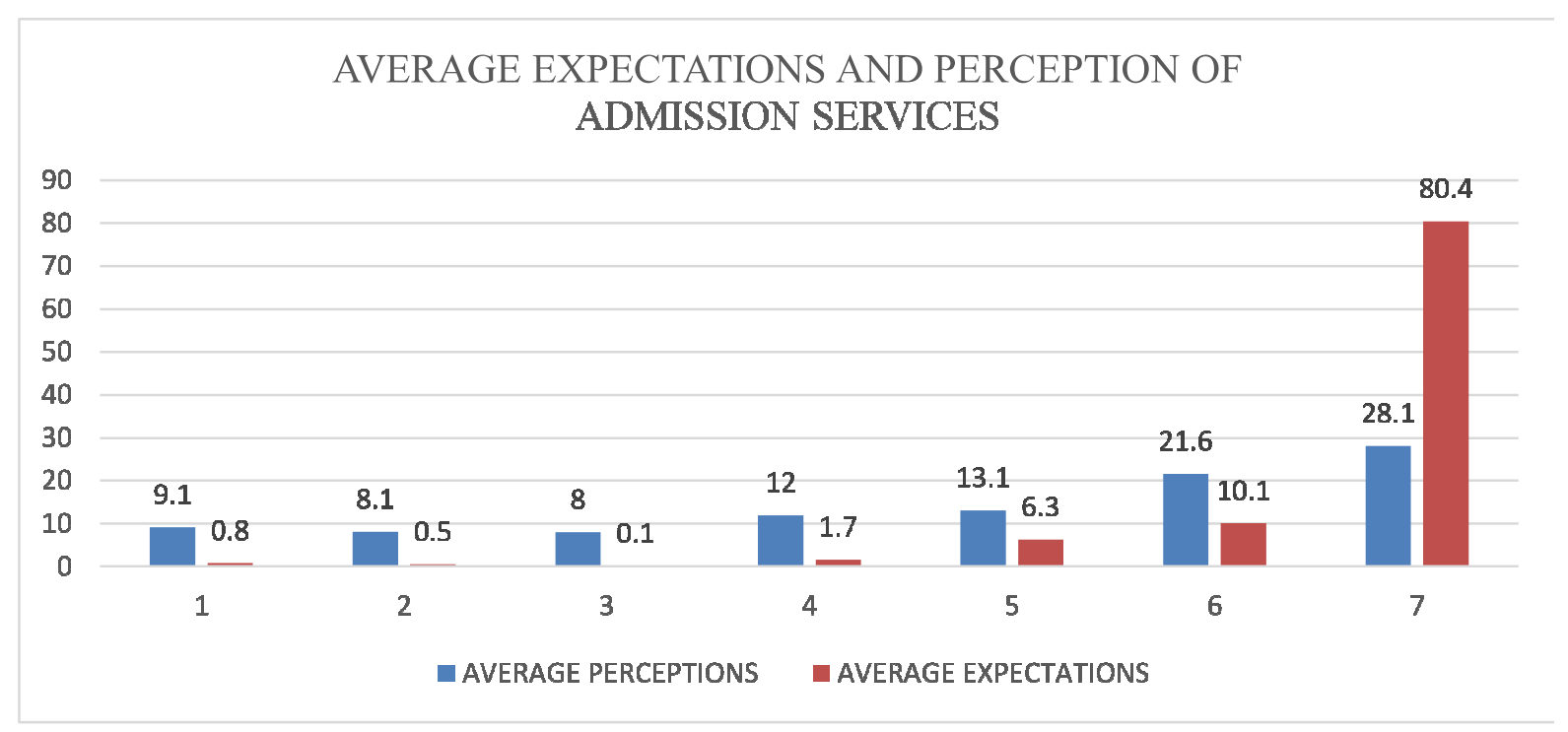

Figure 6. Average expectations and perception of admission services 


\section{Al Macrothink}

Table 11. Respondents' expectations of meal services at the EFSTH in percentages

\begin{tabular}{llllllll}
\hline Variables & SD & D & DS & UD & AS & A & SA \\
\hline $\begin{array}{l}\text { E33.Meals at the EFSTH should always be served } \\
\text { at the right temperature }\end{array}$ & 0.4 & 1.2 & 1.2 & 2.8 & 4.4 & 9.2 & 80.8 \\
$\begin{array}{l}\text { E34.Meals at the EFSTH should be of excellent } \\
\text { quality }\end{array}$ & 0.4 & 2 & 1.2 & 2 & 2.4 & 9.6 & 82.4 \\
$\begin{array}{l}\text { E35.Meals at the EFSTH should be carefully } \\
\text { prepared to suite the case of each individual patient }\end{array}$ & 0.8 & 1.6 & 1.6 & 0.8 & 3.6 & 7.2 & 84.4 \\
$\begin{array}{l}\text { AVERAGE EXPECTATIONS } \\
\text { SUMMARY OF EXPECTATIONS }\end{array}$ & 0.5 & 1.6 & 1.3 & 1.9 & 3.5 & 8.7 & 82.5 \\
\hline
\end{tabular}

\subsection{Respondents' Expectations of the Meal Service at EFSTH}

The table above summarizes the respondent expectations of the meal services. They have a high expectation of the meal services at the EFSTH. Majority of the respondents $80.8 \%$ strongly that meals should always be served at the right temperature, majority of them $82.4 \%$ also strongly agreed that meals should be of excellent quality and finally $84.4 \%$ strongly agreed that meals should be carefully prepared to suit the case of each individual patient.

Table 12. Respondents' perceptions of meal services at the EFSTH in percentages

\begin{tabular}{|c|c|c|c|c|c|c|c|}
\hline Variables & SD & $\mathrm{D}$ & DS & UD & AS & A & SA \\
\hline $\begin{array}{l}\text { P33.Meals in EFSTH are always served at the right } \\
\text { temperature }\end{array}$ & 5.6 & 8 & 7.6 & 14 & 16.4 & 17.2 & 31.2 \\
\hline P34. Meals in EFSTH are of excellent quality & 10.8 & 6 & 12 & 12 & 17.2 & 17.2 & 24.8 \\
\hline $\begin{array}{l}\text { P35. Meals in EFSTH are carefully prepared to suite } \\
\text { the case of everyone patient }\end{array}$ & 17.2 & 8 & 10 & 13.2 & 13.2 & 15.6 & 22.8 \\
\hline AVERAGE PERCEPTION & 11.2 & 7.3 & 9.9 & 13.1 & 15.6 & 16.7 & 26.3 \\
\hline SUMMARY OF PERCEPTION & 28.4 & & & 13.1 & & & 58.5 \\
\hline
\end{tabular}

\subsection{Respondents' Perception of the Meal Service at the EFSTH}

The above summarizes respondents' the perception of the meal services at the EFSTH. The perception level is generally with $31.2 \%$ strongly agreed that meals are served at the right temperature, about meals are of excellent quality $24.8 \%$ strongly and finally meals in EFSTH are carefully prepared to suit the case of each individual patient $22.8 \%$ strongly agreed 


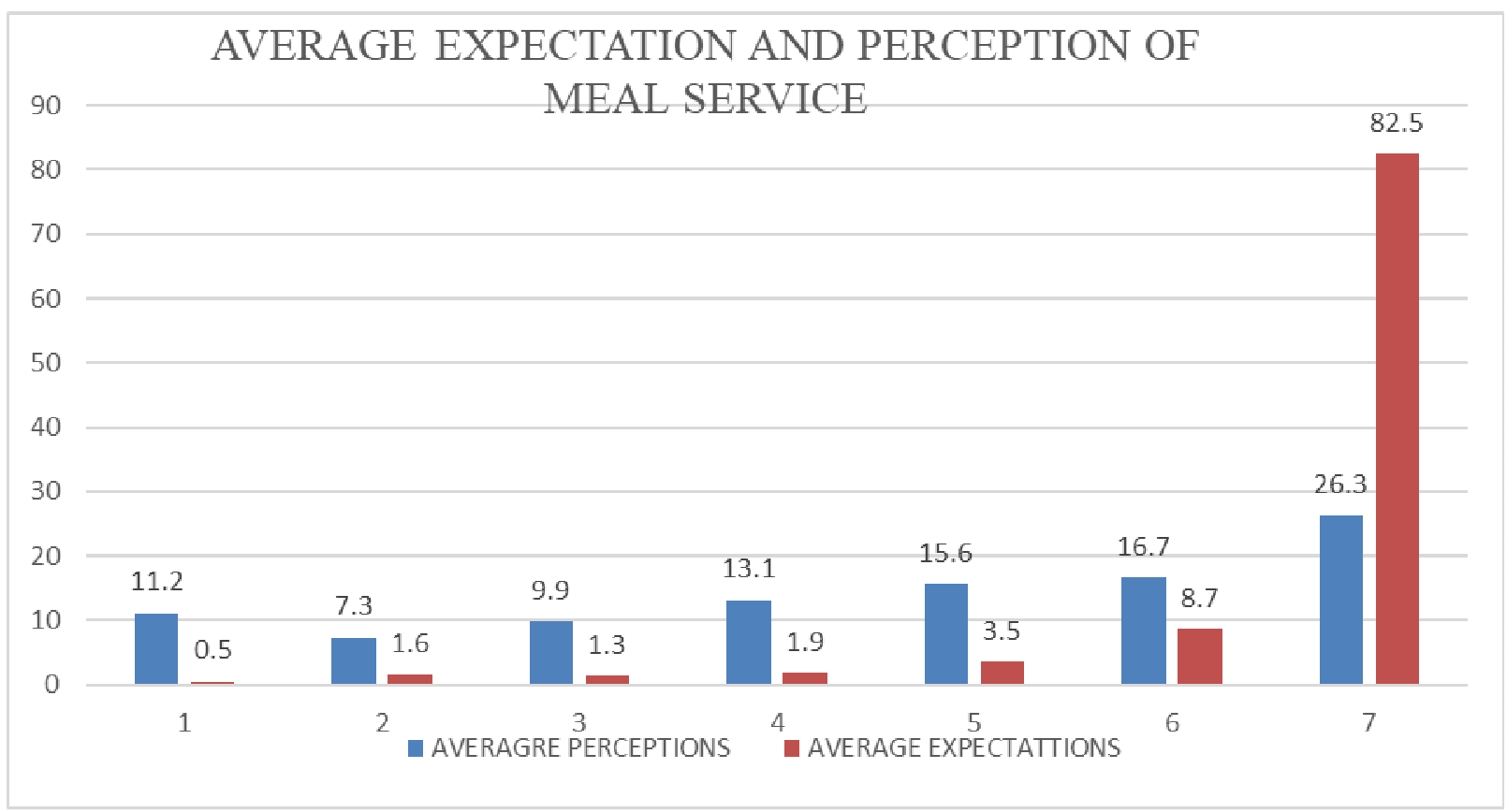

Figure 7. Average expectation and perception of meal services

Table 13. Respondents' expectations of housekeeping services at the EFSTH in percentages

\begin{tabular}{llllllll}
\hline Variables & SD & D & DS & UD & AS & A & SA \\
\hline $\begin{array}{l}\text { E36. Rooms in EFSTH should be visually } \\
\text { appealing }\end{array}$ & 1.6 & 0.4 & 0.8 & 2.4 & 2.8 & 10 & 82 \\
$\begin{array}{l}\text { E37. Rooms and baths in EFSTH should be kept } \\
\text { very clean }\end{array}$ & 0.8 & 1.2 & 2 & 0.8 & 1.2 & 12.8 & 81.2 \\
$\begin{array}{l}\text { E38.Housekeeping staff in EFSTH should } \\
\text { consistently be courteous }\end{array}$ & 2.4 & 0 & 1.2 & 0.4 & 5.6 & 12.8 & 77.6 \\
$\begin{array}{l}\text { AVERAGE EXPECTATIONS } \\
\text { SUMMARY OF EXPECTATIONS }\end{array}$ & 1.6 & 0.5 & 1.3 & 1.2 & 3.2 & 11.9 & 80.23 \\
\hline
\end{tabular}

\subsection{Respondents' Expectations of the Housekeeping Services}

The table above summarizes the respondents' expectations of the room services at the EFSTH. Majority of the respondents $82.0 \%$ strongly agreed that the rooms should be visually appealing, majority of them $81.2 \%$ also strongly agreed that rooms and baths should be kept very clean and finally $77.6 \%$ strongly agreed that the housekeeping staff should consistently be courteous. 


\section{Macrothink}

Business and Management Horizons

ISSN 2326-0297

2019, Vol. 7, No. 1

Table 14. Respondents' perceptions of housekeeping services at the EFSTH in percentages

\begin{tabular}{llllllll}
\hline Variables & SD & D & DS & UD & AS & A & SA \\
\hline P36 Rooms in EFSTH are visually appealing & 10.4 & 8.4 & 6.4 & 9.2 & 16 & 27.2 & 22.4 \\
P37. Rooms and baths in EFSTH are kept very clean & 19.2 & 9.2 & 8 & 9.2 & 15.2 & 22.4 & 16.8 \\
$\begin{array}{l}\text { P38.Housekeeping staff in EFSTH are consistently } \\
\text { courteous }\end{array}$ & 9.2 & 4 & 12 & 10 & 17.2 & 20.8 & 26.8 \\
AVERAGE PERCEPTION & & & & & & & \\
SUMMARY OF PERCEPTION & 12.9 & 7.2 & 8.8 & 9.5 & 16.3 & 23.5 & 22 \\
\hline
\end{tabular}

\subsection{Respondents' Perception of the Housekeeping Services at the EFSTH}

The table above summarizes the respondents' perceptions of the room services at the EFSTH. The perception level is low with $22.4 \%$ strongly agreed that rooms are visually appealing, rooms and baths are kept very clean $20.8 \%$ agree and finally housekeeping staff are consistently courteous $26.8 \%$ strongly agreed.

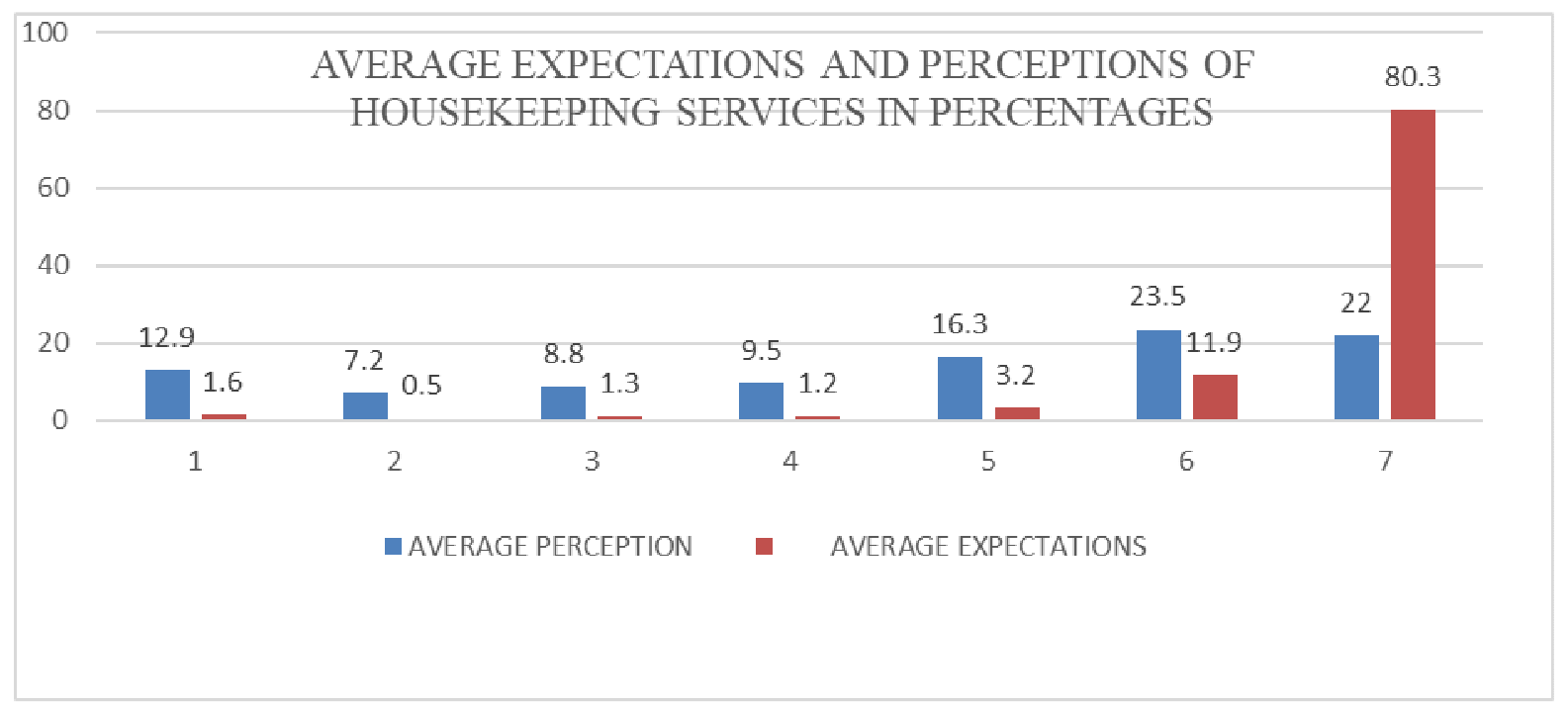

Figure 8. Average expectations and perceptions of housekeeping services

Table 15. Respondents' expectations of discharge services at EFSTH in percentages

\begin{tabular}{llllllll}
\hline Variables & SD & D & DS & UD & AS & A & SA \\
\hline $\begin{array}{l}\text { E39. Accounts office personnel at the EFSTH should } \\
\text { answer questions (e.g. billing, insurance) very }\end{array}$ & 0.4 & 0.4 & 0 & 3.2 & 3.6 & 8.8 & 83.6 \\
adequately & & & & & & & \\
$\begin{array}{l}\text { E40.Accounts personnel at the EFSTH should } \\
\text { consistently be courteous to patients }\end{array}$ & 0.8 & 0.4 & 0.4 & 4 & 8.4 & 11.6 & 74.4 \\
& & & & & & & \\
$\begin{array}{l}\text { AVERAGE EXPECTATIONS } \\
\text { SUMMARY OF EXPECTATTION }\end{array}$ & 0.6 & 0.4 & 0.2 & 3.6 & 6 & 10.2 & 79 \\
\hline
\end{tabular}




\section{Macrothink}

\subsection{Respondents' Expectations of the Discharge Services}

The table above summarizes the respondents' expectations of the services at the EFSTH. Majority of the respondents $83.6 \%$ strongly agreed that account office personnel should answer questions (e.g. billing, insurance) very adequately and $74.4 \%$ also strongly agreed that accounts personnel should be courteous to patients.

Table 16. Respondents' perceptions of the discharge services at EFSTH in percentages

\begin{tabular}{llllllll}
\hline Variables & SD & D & DS & UD & AS & A & SA \\
\hline $\begin{array}{l}\text { P39.Accounts office personnelattheEFSTH answer } \\
\text { questions (e.g. billing, insurance) very adequately }\end{array}$ & 6.4 & 8.4 & 4.8 & 14.8 & 15.2 & 22 & 28.4 \\
& & & & & & & \\
$\begin{array}{l}\text { P40.Accounts personnel at the EFSTH are } \\
\text { consistently courteous to patients }\end{array}$ & 6.4 & 10 & 6.4 & 14 & 15.6 & 22 & 25.6 \\
& & & & & & & \\
AVERAGE PERCEPTION & 6.4 & 9.2 & 5.6 & 14.4 & 15.4 & 22 & 27 \\
SUMMARY OF PERCEPTION & 21.2 & & & 14.4 & & & 64.4 \\
\hline
\end{tabular}

\subsection{Respondents'Perceptions of the Discharge Services}

The table above summarizes the respondents' perception of the services at the EFSTH. The perception level is generally low, with $28.4 \%$ of the respondents strongly agreed that accounts office personnel answer questions (e.g. billing, insurance) very adequately and $25.6 \%$ of them strongly agreed that accounts personnel at the EFSTH are consistently courteous to patients.

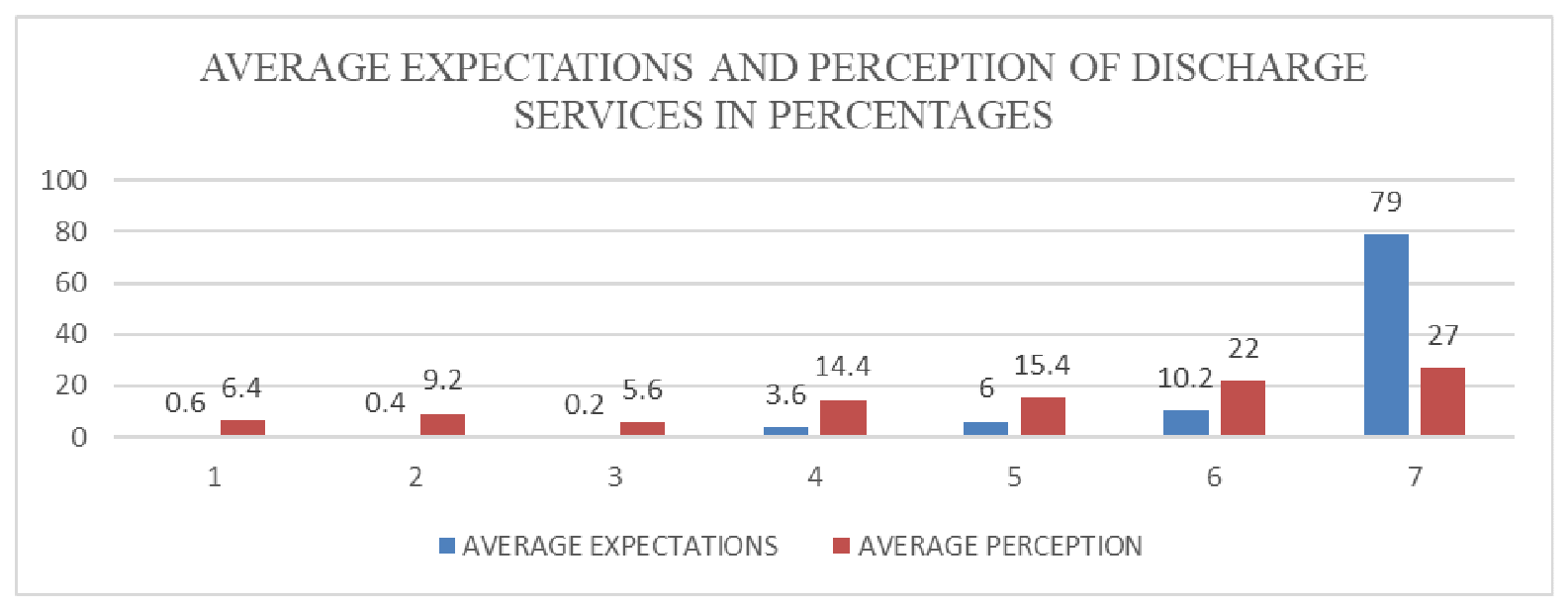

Figure 9. Average expectations and perceptions of discharge services 


\section{Ml Macrothink}

Table 17. Importance of different service features in percentages

\begin{tabular}{llllll}
\hline Variables & LI & NI & N & I & MI \\
\hline Hospital Premises and Employees & 30.4 & 2.4 & 21.2 & 32.8 & 13.2 \\
Medical Doctors & 3.2 & 2.0 & 9.2 & 32.8 & 52.8 \\
Diagnostic Services & 25.2 & 6.8 & 21.6 & 34.0 & 12.4 \\
Nursing Care & 4.0 & 1.2 & 15.2 & 32.0 & 47.6 \\
Admission Personnel & 43.6 & 13.6 & 13.6 & 24.0 & 5.2 \\
Meals & 37.2 & 12.8 & 22.0 & 22.8 & 4.8 \\
Housekeeping & 46.4 & 19.2 & 12.0 & 18.8 & 3.2 \\
Discharge Services & 60.0 & 10.0 & 8.0 & 19.6 & 2.4 \\
\hline
\end{tabular}

\subsection{Importance of Hospital Services}

The respondents were asked to evaluate which feature of the hospital service is most important to them. Majority of the respondents $52.8 \%$ choose medical doctors as the most important, followed by nursing care $47.6 \%$ of the respondents, $13.2 \%$ choose the hospital premises and employees as the most important, followed by the diagnostic services. The rest of the features fall below $10 \%$ as the most important to the respondents, Least important (LI), Not important (NI) Neutral (N), Important (I) Most important (MI).

Table 18. Overall satisfaction with the hospital in percentages

\begin{tabular}{llllll}
\hline Variables & SD & D & N & A & SA \\
\hline Q49. Overall, I am satisfied with hospital service provided & 8.8 & 13.2 & 18.8 & 22.4 & 36.8 \\
Q50. I should choose this hospital again if I need it & 6.4 & 12.4 & 19.2 & 25.6 & 36.4 \\
Q51. I should never recommend this hospital to a friend or relative & 38.8 & 23.2 & 18.4 & 10.8 & 8.8 \\
$\begin{array}{l}\text { Q52. I got excellent value of my money for the hospital services } \\
\text { rendered }\end{array}$ & 7.6 & 12.4 & 26.4 & 27.6 & 26.0 \\
$\begin{array}{l}\text { Q53. I left the hospital without any hospital-caused problems for } \\
\text { me }\end{array}$ & 6.8 & 8.0 & 25.6 & 23.6 & 35.6 \\
$\begin{array}{l}\text { Q54. I left the hospital without any hospital-caused problems for } \\
\text { my baby }\end{array}$ & 15.2 & 4.0 & 51.6 & 14.4 & 14.8 \\
\hline
\end{tabular}

\subsection{Overall Assessment of the Hospital Provided}

The table below summarizes the overall satisfaction of the respondents with the hospital services. The percentage of patients that state that they are satisfied with the hospital was $36.8 \%$ and $36.8 \%$ said they will choose the hospital again if they need it, as for the statement that I should never recommend this hospital to a friend or relative $38.8 \%$ strongly disagreed. I got excellent value for my money for the hospital services $26.4 \%$ were neutral. I left the hospital without any hospital-caused problems for me $35.6 \%$ strongly agreed. 
Table 18. The service features gap score

\begin{tabular}{llll}
\hline Variables & mean expectation & mean perception & gap score \\
\hline Hospital premises and employees & 6.6475 & 5.24 & -1.4075 \\
Doctor services & 6.596153846 & 5.214615385 & -1.3815 \\
Diagnostic services & 6.4975 & 4.9575 & -1.54 \\
Nursing services & 6.7325 & 5.6 & -1.1325 \\
Admission services & 6.64 & 4.89 & -1.75 \\
Meal services & 6.62 & 4.696666667 & -1.9233 \\
Housekeeping services & 2.473333333 & 4.67 & 2.19667 \\
Discharge services & 6.605 & 4.975 & -1.63 \\
\hline AVERAGE UNWEIGHTED SCORE & -1.01772 & & \\
WEIGHTED GAP SCORE & -0.82152 & & \\
\hline
\end{tabular}

\subsection{The Means Gap Scores of Respondents}

The study shows that there exist both positive and negative gaps between the respondents 'expectations and perceptions of the hospital services. The only feature of the hospital service with a positive gap score was housekeeping services 2.19667.

All the other features of the hospital service obtained a negative gap score as summarized in the table below. The average unweighted gap score was -1.01772 and the weighted service gap score was -0.82152 .

Table 19. Correlation between expectations and satisfaction

\begin{tabular}{llll}
\hline & & Expectation Mean score & perception Mean score \\
\hline & Pearson Correlation & 1 & $.482 * *$ \\
Expectation mean score & Sig. (2-tailed) & & .000 \\
& $\mathrm{~N}$ & 250 & 250 \\
& Pearson Correlation & $.482^{* *}$ & 1 \\
Perception mean score & Sig. (2-tailed) & .000 & 250 \\
& $\mathrm{~N}$ & 250 & \\
\hline
\end{tabular}

**. Correlation is significant at the 0.01 level (2-tailed).

\subsection{Correlation Between Satisfaction and Expectations}

The table above summarizes the relationship between expectations and perception. The findings show that there is not a strong positive correlation between expectations of respondents and their perceptions of the hospital services. The relationship is significant at a $\mathrm{p}$ value of 0.01 . This means that the high expectations of patients did not lead to high perceptions about the hospital services.

\section{Discussion}

The findings show that there is not a strong positive correlation between expectations and perception which was not strong. The correlation coefficient was .482 which was significant at a $p$ value of 0.01 . When the mean expectation and mean perception were compared, it was 
discovered that the mean expectation was higher than the perception mean. This implies that there is a gap between expectation and perception, which indicates lack of patients' satisfaction.

This finding is similar with findings of the study done by (Mekonnen \& Enquselassie, 2016) who pointed out that there were differences between pre-consultation expectation and post-consultation experience.

The service quality gap which is a difference between expectation and perception about the dimensions of services quality. The hospital premises and employees (gap score -1.3815), doctors services (gap score -1.3815), diagnostic services (gap score -1.54), nursing services (gap score -1.1325), admission services (gap score -1.75), meals (gap score -1.9233), and discharge services (gap score -1.63). This means that the patients are not satisfied with these service features of the hospital. The only service feature that has a positive gap score was housekeeping (gap score 2.19667). According (Parasuraman et al., 1985) if customers' expectation is greater than performance, then perceived quality is regarded less than satisfactory and a service quality gap arises. This in effect does not necessarily mean that the service is of low quality but rather customer expectations have not been met and therefore customer dissatisfaction occurs and these present opportunities for improving service to meet customer expectations. The positive gap of housekeeping means that the patients are satisfied with the quality of housekeeping services at the hospital.

\subsection{Conclusion}

The aim of this research is to look at the satisfaction of patients about the services at the Edward Francis Small Teaching hospital. The discussion of the findings is to find out whether the research questions have been answered. The following research questions were adapted at the beginning of the study:

What is the satisfaction level of patient about the services provided at the Edward Francis Small Teaching Hospital?

What are the patient's expectations of the services provided at the EFSTH?

What are the patient's perceptions of the services provided at the EFSTH?

How can patient satisfaction be improved at the EFSTH?

The findings of the study can answer the research questions.

The research discovered that the patients have a low level of satisfactions with the services at the EFSTH hospital.

The research also discovered that the patients had a high expectation of the services offered at the EFSTH.

The research discovered that the perceptions of the patients are lower than the expectations of the services at the EFSTH.

The service quality at the EFSTH can be improved by closing the gap between the patients' 
expectations and perceptions.

\subsection{Summary}

This study looked at the satisfaction of patients about the health services at the EFSTH. The instrument used "SERVQUAL" is a valid tool for assessing patient satisfaction and service quality. The questionnaire looked at key aspects of patient's satisfaction, their expectations and perceptions of the services. Eight service features of the hospital were assessed, and they included the hospital premises and employees, diagnostic services, doctor's services, nursing services, meal services, housekeeping services, admission services and discharge services. After a thorough analysis of the data key findings came out to show whether patients seeking care at the hospital were satisfied with the services. Overall the patients had a greater expectation about the hospital services.

However, this high expectation did not match the perceptions of the patients, which were generally lower than the expectations.

Patients' perceptions of health care were very key to their satisfaction and indirectly influenced their loyalty. The service quality is a key indicator of patient satisfaction. Service quality is determined by the gap between the patients' expectations and perceptions.

When the gap is positive the quality of services has meet the expectations of the patients. However, when the gap is negative the quality of services has failed to meet the expectations of the patients.

In this research, the seven of the hospital service features/dimensions had a negative gap score indicating low service quality subsequently leading to low patient satisfaction. Only the housekeeping services had a positive gap score, which indicate high quality service and therefore, indicating that the patients are satisfied with housekeeping services. Clinical service is one of the most important sector of the hospital services. The findings from this study have showed that patients rated the services offered by the doctors, followed by the nurses and the diagnostic services. This has highlighted that these three features are the most important aspect of the hospital services and therefore needs proper attention from the hospital management to improve the services patients received from the healthcare workers working in these areas.

\subsection{Implication to Nursing Practice}

The findings of this research have great implications for the nursing and the healthcare services. The hospital management can use the above findings as an impetus for right actions and attitude required from the staff of the hospitals including doctors, nurses, technicians, admission and discharge personnel, housekeeping and kitchen staff that is needed to satisfy the patients and retain the patients. As EFSTH is the pinnacle of healthcare in the Gambia, findings from this study would also encourage the hospital authorities to focus on creating service strategies that are geared towards maintaining high quality services. This service should create positive experience in the patients to build a good image for the hospital. This will encourage the patients to seek services in the hospital rather than seeking it from other 
facilities that are of less capacity in terms of trained human resources and are costlier to the patients.

Findings from this study can serve as an impetus in establishing healthcare standards and certifications in both the public and private healthcare facilities in the Gambia. This if effectively implemented will no doubt lead to quality healthcare services, which will further translate into good health outcome for patients in our hospitals and health centres. This will go a long way towards improving the health seeking behaviour of the Gambian populace as patients will have confidence in the health sector and would therefore utilize the services.

\subsection{Limitations of the Study}

Finally, the research is not without limitations and one of them includes the fact that only the EFSTH was used to assess the patient satisfaction. It would have been more interesting if another hospital was also included in the study so that the results would be compared and be used as a reference point. Finally, majority of the patients are drawn from the in-patient it would have been prudent if the patients attending outpatient clinics were also included in the study.

In conclusion assessment of patient satisfaction and quality of services is essential for healthcare service delivery. It is imperative to focus on the needs, expectations and perception of the patients to assess their satisfaction about the services they receive. This will assist the health care providers to identify service areas that need improvement to meet patients need.

\section{References}

Aharony, L., \& Strasser, S. (1993). Patient Satisfaction: What we Know about and What we Still Need to Explore. Medical Care Review, 50(1), 49-79. https://doi.org/10.1177/002570879305000104

Anderson, R. T., Camacho, F. T., \& Balkrishnan, R. (2007). Willing to wait?: The influence of patient wait time on satisfaction with primary care. BMC Health Services Research, 7(1). https://doi.org/10.1186/1472-6963-7-31

Bartlett, E. E., Grayson, M., Barker, R., Levine, D. M., Golden, A., \& Libber, S. (1984). The effects of physician communications skills on patient satisfaction; Recall, and adherence. Journal of Chronic Diseases, 37(9-10), 755-764. https://doi.org/10.1016/0021-9681(84)90044-4

Bolton, L. B. D., Aydin, C. E., Donaldson, N. Dns., Brown, D. S., Nelson, M. S. M., \& Harms, D. M. (2003). Nurse Staffing and Patient Perceptions of Nursing Care. Journal of Nursing Administration, 33(11), 607-614.

Camacho, F., Anderson, R., Safrit, A., Jones, A. S., \& Hoffmann, P. (2006). The relationship between patient's perceived waiting time and office-based practice satisfaction. NC Med J, 67(6), 409-413.

Chunlaka, P. (2010). International patients' satisfaction towards nurses' service quality at Samitivej Srinakarin Hospital. Unpublished Master's Thesis). Srinakharinwirot University, 
Thailand.

Retrieved

from

Http://Thesis.

Swu.

Ac/Swuthesis/Bus_Eng_Int_Com/Poramaphorn_C.

$P d f$. Retrieved

from

$\mathrm{http} / / /$ thesis.swu.ac.th/swuthesis/Bus_Eng_Int_Com/Poramaphorn_C.pdf

Crosby, L. A., Evans, K. R., \& Cowles, D. (1990). Relationship Quality in Services Selling: An Interpersonal Influence Perspective. Journal of Marketing, 54(3), 68. https://doi.org/10.2307/1251817

Curtiss, F. R., Fry, R. N., \& Avey, S. G. (2004). Framework for Pharmacy Services Quality Improvement-A Bridge to Cross the Quality Chasm. Journal of Managed Care Pharmacy, $10(1), 60-78$.

Dearmin, J., Brenner, J., \& Migliori, R. (1995). Reporting on QI Efforts for Internal and External Customers. The Joint Commission Journal on Quality Improvement, 21(6), 277-288. https://doi.org/10.1016/S1070-3241(16)30148-1

Dey, P. K., Hariharan, S., \& Brookes, N. (2006). Managing healthcare quality using logical framework analysis. Managing Service Quality: An International Journal, 16(2), 203-222. https://doi.org/10.1108/09604520610650655

Donabedian, A. (1997). The quality of care. Archives of Pathology \& Laboratory Medicine, 121,11 .

Ford, R. C., Bach, S. A., \& Fottler, M. D. (1997). Methods of Measuring Patient Satisfaction in Health Care Organizations. Health Care Management Review Spring 1997, 22(2), 74-89.

Gross, D. A., Zyzanski, S. J., Borawski, E. A., Cebul, R. D., \& Stange, K. C. (1998). Patient satisfaction with time spent with their physician. Journal of Family Practice, 47(2), 133-138.

Horvat, N., \& Kos, M. (2010). Development and Initial Validation of a Patient Satisfaction With Pharmacy Performance Questionnaire (PSPP-Q). Evaluation \& the Health Professions, 33(2), 197-215. https://doi.org/10.1177/0163278710361924

Horvat, N., \& Kos, M. (2011). Slovenian pharmacy performance: a patient-centred approach to patient satisfaction survey content development. International Journal of Clinical Pharmacy, 33(6), 985-996. https://doi.org/10.1007/s11096-011-9572-4

Howard, M., Agarwal, G., \& Hilts, L. (2009). Patient satisfaction with access in two interprofessional academic family medicine clinics. Family Practice, 26(5), 407-412. https://doi.org/10.1093/fampra/cmp049

Huang, X.-M. (1994). Patient attitude towards waiting in an outpatient clinic and its applications. Health Services Management Research, 7(1), 2-8.

Kassam, R., Collins, \& Berkowitz. (2012). Patient satisfaction with pharmaceutical care delivery in community pharmacies. Patient Preference and Adherence, 337. https://doi.org/10.2147/PPA.S29606

Kutney-Lee, A., McHugh, M. D., Sloane, D. M., Cimiotti, J. P., Flynn, L., Neff, D. F., \& Aiken, L. H. (2009). Nursing: a key to patient satisfaction. Health Affairs, 28(4), 
w669-w677.

Leas, B. (2006). \&quot;Patients' Global Ratings of Their Health Care Are Not Associated With the Technical Quality of Their Care\&quot; American Journal of Medical Quality, 21(5), 354-355.

MacKeigan, L. D., \& Larson, L. N. (1989). Development and validation of an instrument to measure patient satisfaction with pharmacy services. Medical Care, 522-536.

Malewski, D. F., Ream, A., \& Gaither, C. A. (2015). Patient satisfaction with community pharmacy: Comparing urban and suburban chain-pharmacy populations. Research in Social and Administrative Pharmacy, 11(1), 121-128. https://doi.org/10.1016/j.sapharm.2014.05.001

Mekonnen, A. B., \& Enquselassie, F. (2016). Patient expectations and their satisfaction in the context of public hospitals. Patient Preference and Adherence, Volume 10, 1919-1928. https://doi.org/10.2147/PPA.S109982

Muhondwa, E. P. Y., Leshabari, M. T., Mwangu, M., Mbembati, N., \& Ezekiel, M. J. (2008). Patient satisfaction at the Muhimbili national hospital in Dar Es Salaam, Tanzania. Retrieved from https://tspace.library.utoronto.ca/handle/1807/39185

O’Toole, R. V., Castillo, R. C., Pollak, A. N., MacKenzie, E. J., \& Bosse, M. J. (2008). Determinants of Patient Satisfaction After Severe Lower-Extremity Injuries. J Bone Joint Surg Am, 90(6), 1206-1211. https://doi.org/10.2106/JBJS.G.00492

Pakdil, F., \& Harwood, T. N. (2005). Patient satisfaction in a preoperative assessment clinic: an analysis using SERVQUAL dimensions. Total Quality Management \& Business Excellence, 16(1), 15-30. https://doi.org/10.1080/1478336042000255622

Parasuraman, A., Zeithaml, V. A., \& Berry, L. L. (1985). A Conceptual Model of Service Quality and Its Implications for Future Research. Journal of Marketing, 49(4), 41. https://doi.org/10.2307/1251430

Pascoe, G. C. (1983). Patient satisfaction in primary health care: a literature review and analysis. Evaluation and Program Planning, 6(3-4), 185-210.

Torscon, P. J. (n.d.). Patient Satisfaction: the Hospitalist's Role. Retrieved February 3, 2017, from

http://www.the-hospitalist.org/hospitalist/article/122984/patient-satisfaction-hospitalists-role

Peprah, A. A., \& Atarah, B. A. (2014). Assessing Patient's Satisfaction using SERVQUAL Model: A Case of Sunyani Regional Hospital, Ghana. International Journal of Business and Social Research, 4(2), 133-143.

Qin, H., \& Prybutok, V. R. (2009). Perceived Service Quality in the Urgent Care Industry. Retrieved from http://swdsi.org/swdsi2009/Papers/9N03.pdf

Rohini, R., \& Mahadevappa, B. (2006). Service Quality in Bangalore Hospitals - an Empirical Study. Journal of Services Research, 6(1), 59-84. 


\section{Macrothink}

Safavi, K. (2006). Patient-Centered Pay for Performance: Are We Missing the Target? Journal of Healthcare Management, 51(4), 215-218.

Sajid, M. S., \& Baig, M. K. (2007). Quality of health care: an absolute necessity for public satisfaction. International Journal of Health Care Quality Assurance, 20(6), 545-548.

Sitzia, J., \& Wood, N. (1997). Patient satisfaction: A review of issues and concepts. Social Science \& Medicine, 45(12), 1829-1843. https://doi.org/10.1016/S0277-9536(97)00128-7

Sommers, P. A., Dropik, R., Heilman, G., \& Vaughan, T. (2007). Patient satisfaction in 21st century medicine: revolution or evolution? The Journal of Medical Practice Management: $M P M, 23(3), 157-162$.

Trout, A., Magnusson, A. R., \& Hedges, J. R. (2000). Patient Satisfaction Investigations and the Emergency Department: What Does the Literature Say? Academic Emergency Medicine, 7(6), 695-709. https://doi.org/10.1111/j.1553-2712.2000.tb02050.x

van Uden, C. .J. (2006). Development of out-of-hours primary care by general practitioners (GPs) in The Netherlands: from small-call rotations to large-scale GP cooperatives. Development of out-of-Hours Primary Care by General Practitioners (GPS) in The Netherlands: From Small-Call Rotations to Large-Scale GP Cooperatives., 38(8), 565-569.

Vranceanu, A.-M., \& Ring, D. (2011). Factors Associated With Patient Satisfaction. The Journal of Hand Surgery, 36(9), 1504-1508. https://doi.org/10.1016/j.jhsa.2011.06.001

Zoller, J. S., Lackland, D. T. D., \& Silverstein, M. D. (2001). Predicting Patient Intent to Return from Satisfaction Scores. [Miscellaneous Article]. Journal of Ambulatory Care Management, 24(1), 44-50.

\section{Copyrights}

Copyright for this article is retained by the author(s), with first publication rights granted to the journal.

This is an open-access article distributed under the terms and conditions of the Creative Commons Attribution license (http://creativecommons.org/licenses/by/4.0/). 